\title{
DEVELOPMENT AND VALIDATION OF RP-LC AND UV SPECTROPHOTOMETRIC METHODS TO ASSAY BROMOPRIDE IN ORAL AND INJECTABLE SOLUTIONS
}

\author{
Márcia Camponogara Fontana, Felipe Kellermann Hurtado, Micheli Wrasse, Aline Augusti Boligon, Tarcieli Pozzebon \\ Venturini, Clarice Madalena Bueno Rolim e Ruy Carlos Ruver Beck* \\ Departamento de Farmácia Industrial, Centro de Ciências da Saúde, Universidade Federal de Santa Maria, Av. Roraima 1000, \\ 97105-900 Santa Maria - RS, Brasil
}

Recebido em 26/2/09; aceito em 15/6/09; publicado na web em 25/11/09

\begin{abstract}
A reversed-phase liquid chromatographic (LC) and ultraviolet (UV) spectrophotometric methods were developed and validated for the assay of bromopride in oral and injectable solutions. The methods were validated according to ICH guideline. Both methods were linear in the range between $5-25 \mu \mathrm{gL}^{-1}(\mathrm{y}=41837 \mathrm{x}-5103.4, \mathrm{r}=0.9996$ and $\mathrm{y}=0.0284 \mathrm{x}-0.0351, \mathrm{r}=1$, respectively). The statistical analysis showed no significant difference between the results obtained by the two methods. The proposed methods were found to be simple, rapid, precise, accurate, and sensitive. The LC and UV methods can be used in the routine quantitative analysis of bromopride in oral and injectable solutions.
\end{abstract}

Keywords: bromopride; reversed-phase liquid chromatography; ultraviolet spectrophotometry.

\section{INTRODUCTION}

Bromopride (4-amino-5-bromo- $N$-(2-diethylaminoethyl)-2methoxybenzamide) (Figure 1), a white crystalline powder, is the bromo-analogue of metoclopramide, being both benzamide derivatives. Bromopride stimulates the motility of the gastrointestinal tract, enhances gastric emptying rate, and presents antiemetic properties. Bromopride is used to treat a variety of gastrointestinal disorders. The main action of bromopride is related to blockade of dopamine 2-receptors in the central nervous system and gastrointestinal tract. Similar to other benzamide derivatives, the gastrointestinal tract stimulation by bromopride appears to be mediated at least in part by its indirect cholinergic activity. ${ }^{1}$<smiles>CCN(CC)CCNC(=O)c1cc(Br)c(N)cc1OC</smiles>

Figure 1. Chemical structure of bromopride

Some techniques have been used to determine bromopride in different biological matrices. Such methods include liquid chromatography-electrospray tandem mass spectrometry, ${ }^{2}$ high-performance liquid chromatography with UV detection, ${ }^{3-5}$ thin-layer chromatography and gas chromatography. ${ }^{6}$ The pharmacopoeia does not present methods for the assay of bromopride in oral and injectable solutions. To date, there are no previous reports focused on the development and validation of analytical methods for the quantitative analysis of bromopride as active substance in pharmaceutical dosage form.

Considering the lack of methods available to assay bromopride in pharmaceutical formulations, this work describes the development and validation of reversed-phase liquid chromatographic (RP-LC) and UV spectrophotometric methods for the determination of bromopride in pharmaceutical dosage forms, establishing procedures for their

\footnotetext{
*e-mail: ruybeck@smail.ufsm.br
}

quality control. Both methods have been applied for the quantitative analysis of bromopride in oral and injectable solutions.

\section{EXPERIMENTAL}

\section{Chemicals}

Bromopride reference substance (assigned purity 99.11\%) was purchased from DEG Importadora de Produtos Químicos Ltda (São Paulo, Brazil). Digesan ${ }^{\circledR}$ (Sanofi-Synthelabo), oral and injectable solutions containing 4 and $5 \mathrm{mg} \mathrm{mL}^{-1}$ of bromopride, respectively, was obtained from the market (Batches 6V2619 and 6Y002, respectively). Gradient-grade LiChrosolv acetonitrile and methanol were purchased from Merck (Darmstadt, Germany). Monobasic sodium phosphate $\left(\mathrm{KH}_{2} \mathrm{PO}_{4}\right)$ and triethylamine (TEA) were also obtained from Merck. Hydrochloric acid was obtained from Tedia (Fairfield, USA). Water was purified with WaterPro ${ }^{\mathrm{TM}}$ PS, Labconco system (MO, USA). Bromopride oral solution was labeled to contain the following excipients: sodium metabisulfite, methylparaben, propylparaben, sodium saccharin, disodium edetate, hydrochloric acid and water. Bromopride injectable solution was labeled to contain the following excipients: hydrochloric acid, sodium chloride and water.

\section{Instrumentation and analytical conditions}

The LC method was performed on a Shimadzu LC system (Kyoto, Japan) equipped with a CBM-20A system controller, LC-20AT

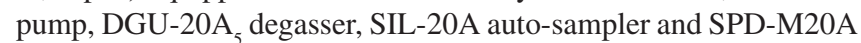
photodiode array detector (PAD). Analytical separation was performed on a Phenomenex (Torrance, USA) Gemini $\mathrm{C}_{18}$ column $(150 \times$ $4.6 \mathrm{~mm}$ i.d., $5 \mu \mathrm{m}$ particle size $)$ coupled to a $\mathrm{C}_{18}$ guard column $(40 \times$ $3.0 \mathrm{~mm}$ i.d., $4 \mu \mathrm{m}$ ). The isocratic mobile phase was a mixture of 10 $\mathrm{mM} \mathrm{KH} \mathrm{PO}_{4}+0.1 \%$ TEA (pH 3.0 adjusted with phosphoric acid): acetonitrile $(80: 20, \mathrm{v} / \mathrm{v})$, performed at room temperature $\left(25 \pm 1^{\circ} \mathrm{C}\right)$, which was pumped at a flow-rate of $1.0 \mathrm{~mL} \mathrm{~min}^{-1}$. This was filtered through a $0.45 \mu$ m nylon membrane filter (Sartorius, Germany) and degassed before used. The injection volume was $20 \mu \mathrm{L}$ (variable injection volume valve -0.1 to $100 \mu \mathrm{L}$ ). The detection was achieved with a PAD at $310 \mathrm{~nm}$ (Figure 2). 


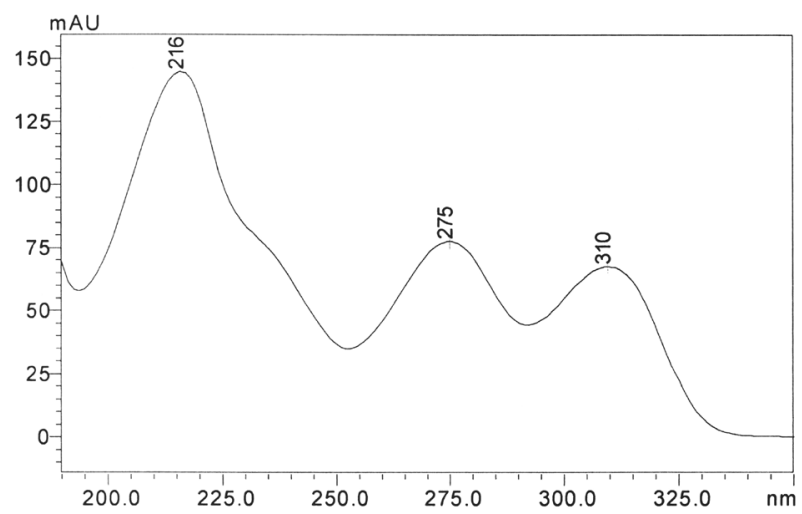

Figure 2. UV spectra of bromopride reference standard by HPLC-DAD at $15 \mu g m L^{-1}$

The UV spectrophotometric method for quantitative assay of bromopride in oral and injectable solutions was performed on a Shimadzu UV 1601 PC spectrophotometer (Kyoto, Japan) equipped with $1 \mathrm{~cm}$ quartz cells with detection at $310 \mathrm{~nm}$ and $0.1 \mathrm{M}$ hydrochloric acid was used as diluent.

\section{Preparation of reference solution}

\section{LC method}

An accurately weighed $10 \mathrm{mg}$ portion of bromopride reference standard was transferred to a $100 \mathrm{~mL}$ volumetric flask and dissolved in methanol (final concentration $=100 \mu \mathrm{g} \mathrm{mL}^{-1}$ ). This solution was diluted with ultra-pure water to give five standard solutions with different concentrations of bromopride (5.0, 10.0, 15.0, 20.0, and $\left.25.0 \mu \mathrm{g} \mathrm{mL}^{-1}\right)$, which were used in the analytical curve for the linearity evaluation.

\section{UV method}

Stock standard solution $\left(100 \mu \mathrm{gL}^{-1}\right)$ was prepared by dissolving $10.0 \mathrm{mg}$ bromopride reference standard in $100.0 \mathrm{~mL}$ of $0.1 \mathrm{M}$ hydrochloric acid. The stock standard solution was diluted with 0.1 $\mathrm{M}$ hydrochloric acid to give five standard solutions with different concentrations of bromopride $\left(5.0,10.0,15.0,20.0\right.$, and $\left.25.0 \mu \mathrm{g} \mathrm{mL}^{-1}\right)$, which were used in the analytical curve for the linearity evaluation.

\section{Preparation of sample solution}

\section{LC method}

An amount equivalent to $10 \mathrm{mg}$ of bromopride, present in oral and injectable solutions, was transferred to a $100 \mathrm{~mL}$ volumetric flask and diluted with methanol to obtain a concentration of $100 \mu \mathrm{g} \mathrm{mL} \mathrm{L}^{-1}$. These solutions were diluted with ultra-pure water to obtain final concentrations of $15 \mu \mathrm{g} \mathrm{mL} \mathrm{m}^{-1}$ and filtered through a $0.45 \mu \mathrm{m}$ nylon membrane filter (Sartorius, Germany) before LC analysis.

\section{UV method}

An amount equivalent to $10 \mathrm{mg}$ of bromopride, present in oral and injectable solutions, was transferred to a $100 \mathrm{~mL}$ volumetric flask and diluted with $0.1 \mathrm{M} \mathrm{HCl}$ to obtain concentrations of $100 \mu \mathrm{g}$ $\mathrm{mL}^{-1}$. These samples were diluted with $0.1 \mathrm{M} \mathrm{HCl}$ to obtain a final concentration of $15 \mu \mathrm{g} \mathrm{mL}^{-1}$ before analysis on the spectrophotometer.

\section{Method validation}

Validation was carried out assessing the following parameters: linearity, range, specificity, precision, accuracy, detection and quantification limits, according to the International Conference on Harmonization (ICH) guidelines for validation of analytical procedures. ${ }^{7,8}$ The system suitability test was also carried out to evaluate the reproducibility of the analytical system, using five replicate injections of a reference solution. The parameters measured were injection repeatability, retention time, theoretical plates, peak symmetry, and capacity factor.

\section{Linearity}

The analytical curves were obtained with five concentrations of reference solution in the range of $5-25 \mu \mathrm{g} \mathrm{mL} L^{-1}$ for the spectrophotometric and LC methods. Each solution was prepared in triplicate. The linearity was evaluated by linear regression analysis by the leastsquare regression method, which was used to calculate the correlation coefficient, y-intercept and slope of the regression line.

\section{Precision}

The precision of the procedures was determined by repeatability (intra-day) and intermediate precision (inter-day). Repeatability was evaluated assaying six determinations at the same concentration (15 $\mu \mathrm{g} \mathrm{mL}^{-1}$ ), during the same day, under the same experimental conditions. Intermediate precision was analyzed comparing the assays in six determinations at the same concentration $\left(15 \mu \mathrm{g} \mathrm{mL}^{-1}\right)$ during three different days. Precision (repeatability and intermediate precision) was expressed as relative standard deviation (RSD\%).

\section{Accuracy}

Accuracy was evaluated assaying samples of a known concentration $\left(7.5 \mu \mathrm{g} \mathrm{mL}^{-1}\right)$ spiked with three different concentrations of standard solution $\left(3.75,7.50\right.$ and $\left.11.25 \mu \mathrm{gL}^{-1}\right)$, at three different levels (lower, medium and upper concentration), giving sample solutions with concentrations of $11.25,15.00$ and $18.75 \mu \mathrm{g} \mathrm{mL}^{-1}$. The accuracy was calculated as the percentage of the drug recovered from the formulation and also expressed as the relative standard deviation (RSD) between the measurements.

\section{Specificity}

The specificity of the LC method was evaluated through the analysis of a placebo solution. The placebo consisted of all the excipients without the active ingredient. For both methods, the interference from the formulation matrix was evaluated. The system response was examined for the presence of interference or overlaps with bromopride responses.

\section{Limit of detection and limit of quantification}

The limit of detection (LOD) and limit of quantification (LOQ) were calculated based on the standard deviation of the response and the slope using three independent analytical curves, as defined by ICH. ${ }^{7}$ LOD and LOQ were calculated as 3.3 and $10 \sigma / \mathrm{S}$, respectively, where $\sigma$ is the standard deviation of the response and $\mathrm{S}$ is the slope of the calibration curve.

\section{Method comparison}

The chromatographic and spectrophotometric methods to assay bromopride in pharmaceutical formulations proposed in our study were compared using statistical analysis by Student's t-test. Six samples of each pharmaceutical dosage forms were analyzed by both methods (LC and UV). 


\section{RESULTS AND DISCUSSION}

\section{LC method}

A simple RP-LC method was developed to assay bromopride in pharmaceutical formulations. The method was optimized to provide a good separation of the components (acceptable theoretical plates and resolution between peaks) with a sufficient sensitivity and suitable peak symmetry (peak tailing factor $<2)^{9}$ in a short run. For this purpose, analytical column, solvent selection, mobile phase composition, flow-rate, and detector wavelength were studied. The chromatographic separation was achieved using a reversed-phase $\mathrm{C}_{18}$ column because it is suitable to analyze bromopride with adequate resolution and symmetrical peak shapes. The chromatograms of bromopride reference standard, samples, and placebo solutions are demonstrated in Figure 3. Analyzing this figure, it can be observed that the proposed LC method is specific since no interfering peaks were observed in the placebo samples. In order to confirm this absence of interference, a peak-purity evaluation using the photodiode-array (PDA) was carried out. These analyses showed that no impurities and/or excipients were co-eluting with the bromopride peak. In addition, the retention time $(5.1 \mathrm{~min})$ allows rapid determination of the drug, which is important for routine analysis. Besides the presence of methyl and propyl parabens in the oral solutions, as preservative, the corresponding peaks were not observed in the chromatograms due to their lack of UV absorption at $310 \mathrm{~nm}$. Methyl and propyl parabens presented peak maxima around $254 \mathrm{~nm}$ in acid solution. ${ }^{10}$

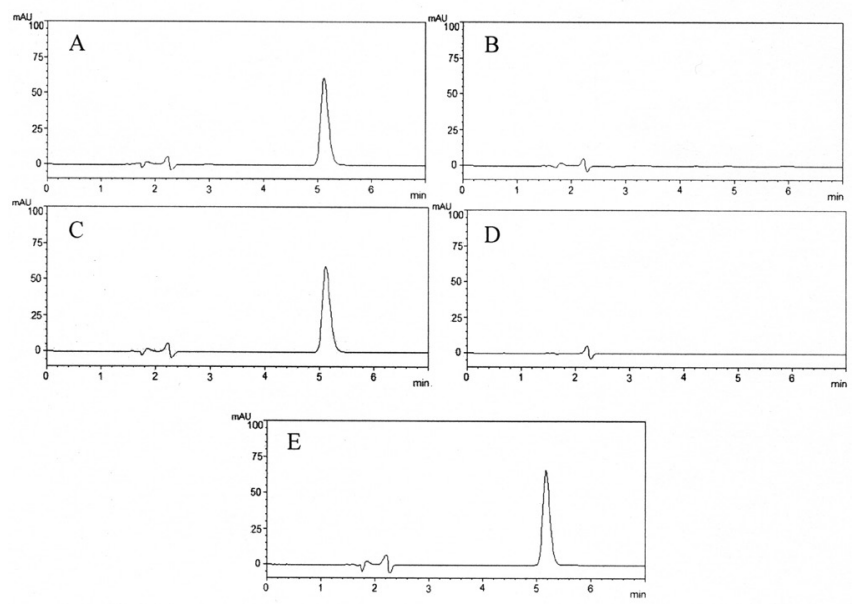

Figure 3. Chromatograms of bromopride in oral and injectable solution at 15 $\mu \mathrm{g} m L^{-1}(A$ and $C)$, their respective placebos (B and $\left.D\right)$ and reference standard solution (E) at $15 \mu \mathrm{g} \mathrm{mL}^{-1}$

The analytical curves for bromopride were constructed by plotting concentration versus peak area. A good linearity was observed in the range between 5 and $25 \mu \mathrm{g} \mathrm{mL}$. The linear equation obtained by the least-square method was $y=41837 x-5103(n=3)$ showing an adequate correlation coefficient $(r=0.9996)$. LOD and LOQ were 0.15 and 0.50 $\mu \mathrm{g} \mathrm{mL}{ }^{-1}$, respectively. These low values indicate a good sensitivity of the proposed method. These data were validated by means of ANOVA, showing a linear regression with no deviation from linearity.

The results obtained for precision are presented in Table 1. All RSD values were lower than $1.0 \%$, indicated good intra-day and interday precision. ${ }^{11,12}$ Regarding the accuracy evaluation, good recoveries (100-102 \%) were obtained (Table 2). The percent recovery indicated good accuracy ${ }^{13}$ and, consequentially, an agreement between the theoretical value and the real value of concentration. ${ }^{11}$ These results demonstrated the adequate precision and accuracy of the developed LC method to assay bromopride in such formulations.
Table 1. Repeatability (intra-day precision) and intermediate precision (inter-day) of oral and injectable solutions determined by the LC method

\begin{tabular}{lccc}
\hline & $\begin{array}{c}\text { Mean } \pm \text { SD } \\
\left(\mu \mathrm{gL}^{-1}\right)\end{array}$ & $\begin{array}{c}\text { Recovery } \\
(\%)\end{array}$ & $\begin{array}{c}\text { RSD } \\
(\%)\end{array}$ \\
\hline Oral solution & & & \\
Intra-day $(\mathrm{n}=6)$ & $15.07 \pm 0.04$ & 100.50 & 0.32 \\
Inter-day & & & \\
Day 1 $(\mathrm{n}=6)$ & $15.08 \pm 0.05$ & 100.50 & 0.33 \\
Day 2 $(\mathrm{n}=6)$ & $15.10 \pm 0.04$ & 100.67 & 0.27 \\
Day 3 $(\mathrm{n}=6)$ & $15.01 \pm 0.01$ & 100.05 & 0.05 \\
Injectable solution & & & \\
Intra-day $(\mathrm{n}=6)$ & $15.03 \pm 0.03$ & 100.25 & 0.19 \\
Inter-day & & & \\
Day 1 $(\mathrm{n}=6)$ & $15.04 \pm 0.03$ & 100.26 & 0.20 \\
Day 2 $(\mathrm{n}=6)$ & $15.07 \pm 0.04$ & 100.49 & 0.28 \\
Day 3 $(\mathrm{n}=6)$ & $15.05 \pm 0.05$ & 100.35 & 0.34 \\
Mean \pm SD $(\mathrm{n}=18)$ & $15.05 \pm 0.04$ & 100.41 & 0.30 \\
\hline
\end{tabular}

Table 2. Accuracy of oral and injectable solutions by the LC method

\begin{tabular}{lcccc}
\hline & $\begin{array}{c}\text { Added } \\
\left(\mu \mathrm{g} \mathrm{mL}^{-1}\right)\end{array}$ & $\begin{array}{c}\text { Found } \\
\left(\mu \mathrm{g} \mathrm{mL}^{-1}\right)\end{array}$ & $\begin{array}{c}\text { Recovery } \\
(\%)\end{array}$ & $\begin{array}{c}\text { RSD } \\
(\%)\end{array}$ \\
\hline Oral solution & 3.75 & $3.78 \pm 0.01$ & 100.70 & 0.30 \\
& 7.50 & $7.51 \pm 0.01$ & 100.17 & 0.11 \\
& 11.25 & $11.27 \pm 0.01$ & 100.17 & 0.08 \\
Injectable & 3.75 & $3.76 \pm 0.01$ & 100.41 & 0.24 \\
solution & 7.50 & $7.51 \pm 0.01$ & 100.19 & 0.16 \\
& 11.25 & $11.28 \pm 0.02$ & 100.32 & 0.17 \\
\hline
\end{tabular}

\section{UV method}

The UV method for the assay of bromopride was developed as an alternative technique, considering its rapid and low-cost as well as its simple instrumentation compared with other techniques. Since bromopride is freely soluble in $0.1 \mathrm{M} \mathrm{HCl}$ this solution was chosen as diluent for the UV assay. The UV spectra of bromopride reference standard, bromopride oral and injectable solutions are represented in Figure 4. As can be seen in Figure 4, the UV spectra from injectable solution overrides the UV spectra obtained for the reference standard solution. As explained previously, the presence of methyl and propyl parabens in the oral solution did not show any interference on the UV spectra because their lack of absorption at $310 \mathrm{~nm} .{ }^{10}$

Good linearity was observed in the $5.0-25.0 \mu \mathrm{g} \mathrm{mL}-1$ range, as previously observed for the LC method. The linear equation obtained by the least-square method was $\mathrm{y}=0.0284 \mathrm{x}-0.0351$ showing an adequate correlation coefficient $(\mathrm{r}=1)$. Data were validated by means of ANOVA, which demonstrated linear regression with no linearity deviation. The LOD and LOQ of the UV method were 0.48 and 1.60 $\mu \mathrm{g} \mathrm{mL}{ }^{-1}$, respectively. Although LOD and LOQ of the UV method were higher than those obtained for the LC method $\left(0.15\right.$ and $0.50 \mu \mathrm{gL}^{-1}$, respectively), the results from both methods show their good sensitivity to assay bromopride in the concentration range proposed in our method.

Regarding the evaluation of the precision and accuracy of the UV method (Tables 3 and 4, respectively), the results are similar to those obtained for the LC method. All RSD values were lower than 


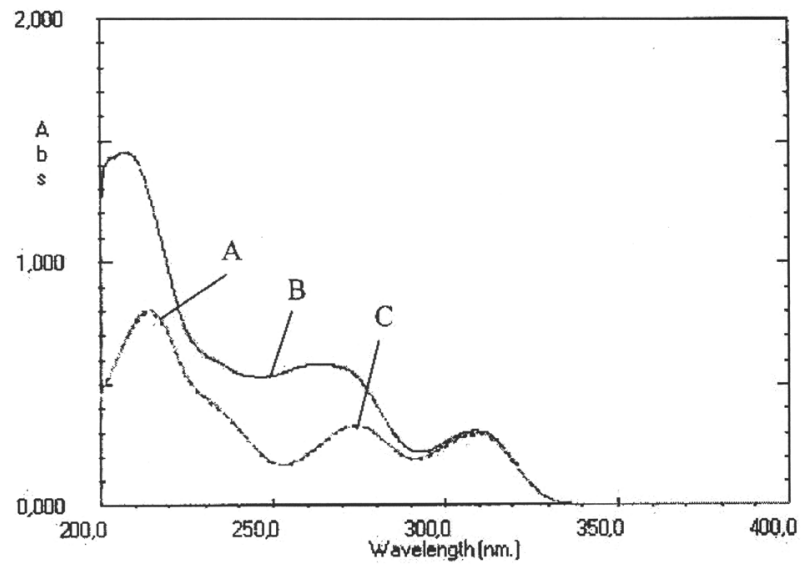

Figure 4. UV spectra of bromopride reference standard (A), bromopride oral (B) and injectable $(C)$ solutions prepared in $0.1 \mathrm{M} \mathrm{HCl} \mathrm{at} 15 \mu \mathrm{g} \mathrm{mL^{-1 }}$

Table 3. Repeatability (intra-day precision) and intermediate precision (inter-day) of oral and injectable solutions determined by the UV method

\begin{tabular}{|c|c|c|c|}
\hline & $\begin{array}{c}\text { Mean } \pm \text { SD } \\
\left(\mu \mathrm{g} \mathrm{mL} L^{-1}\right)\end{array}$ & $\begin{array}{c}\text { Recovery } \\
(\%)\end{array}$ & $\begin{array}{l}\mathrm{RSD} \\
(\%)\end{array}$ \\
\hline \multicolumn{4}{|l|}{ Oral solution } \\
\hline Intra-day $(n=6)$ & $15.03 \pm 0.04$ & 100.25 & 0.29 \\
\hline \multicolumn{4}{|l|}{ Inter-day } \\
\hline Day $1(n=6)$ & $15.04 \pm 0.04$ & 100.26 & 0.30 \\
\hline Day $2(n=6)$ & $15.03 \pm 0.02$ & 100.18 & 0.12 \\
\hline Day $3(n=6)$ & $15.07 \pm 0.03$ & 100.49 & 0.21 \\
\hline \multicolumn{4}{|l|}{ Injectable solution } \\
\hline Intra-day $(n=6)$ & $15.02 \pm 0.02$ & 100.18 & 0.19 \\
\hline \multicolumn{4}{|l|}{ Inter-day } \\
\hline Day $1(n=6)$ & $15.03 \pm 0.03$ & 100.18 & 0.19 \\
\hline Day $2(n=6)$ & $15.09 \pm 0.02$ & 100.57 & 0.12 \\
\hline Day $3(n=6)$ & $15.05 \pm 0.05$ & 100.34 & 0.32 \\
\hline $\begin{array}{l}\text { Mean } \pm \text { SD } \\
(n=18)\end{array}$ & $15.05 \pm 0.04$ & 100.36 & 0.26 \\
\hline
\end{tabular}

$1.0 \%$ and recoveries were in the range of $100-102 \%$. These results demonstrated adequate precision and accuracy of the UV method.

\section{Comparison between the LC and UV methods}

LC and UV methods were compared using Student's t-test. There was no significant difference between the experimental values obtained through the analysis of six samples using the two methods, regardless of the dosage form ( $p>0.05)$. This result shows that the 2 methods are equivalent for the quantitative determination of bromopride in oral or injectable solutions, as showed by some authors for other drugs. ${ }^{14-17}$

\section{CONCLUSIONS}

Rapid, specific and reliable LC and UV methods were developed and validated for the assay of bromopride in oral and injectable solutions. Both analytical methods are simple, precise, accurate, sensitive,
Table 4. Accuracy of oral and injectable solutions by the UV method

\begin{tabular}{lcccc}
\hline & $\begin{array}{c}\text { Added } \\
\left(\mu \mathrm{g} \mathrm{mL}^{-1}\right)\end{array}$ & $\begin{array}{c}\text { Found } \\
\left(\mu \mathrm{g} \mathrm{mL}^{-1}\right)\end{array}$ & $\begin{array}{c}\text { Recovery } \\
(\%)\end{array}$ & $\begin{array}{c}\text { RSD } \\
(\%)\end{array}$ \\
\hline Oral solution & 3.75 & $3.79 \pm 0.03$ & 101.05 & 0.93 \\
& 7.50 & $7.53 \pm 0.02$ & 100.41 & 0.27 \\
& 11.25 & $11.28 \pm 0.02$ & 100.30 & 0.18 \\
\hline Injectable & 3.75 & $3.79 \pm 0.03$ & 101.14 & 0.92 \\
solution & 7.50 & $7.55 \pm 0.03$ & 100.62 & 0.47 \\
& 11.25 & $11.29 \pm 0.02$ & 100.36 & 0.18 \\
\hline
\end{tabular}

and linear in the concentration range of 5-25 $\mu \mathrm{g} \mathrm{mL} \mathrm{m}^{-1}$, allowing complete interchange, encouraging its application for quality control of bromopride in oral or injectable solutions. In addition, the proposed UV method uses no organic solvent avoiding the formation of dangerous residues promoting benefits to the public health and the environment.

\section{ACKNOWLEDGEMENTS}

The authors thank the financial support of CAPES (Coordenação de Aperfeiçoamento de Pessoal de Nível Superior)/Brazil.

\section{REFERENCES}

1. Tanaka, R.; Hirayama, N.; Anal. Sci. 2004, 20 , x79.

2. Nazare, P.; Massaroti, P.; Duarte, L. F.; Campos, D. R.; Marchioretto, M. A. M.; Bernasconi, G.; Calafatti, S.; Barros, F. A. P.; Meurer, E. C.; Pedrazzoli, J.; Moraes, L. A. B.; J. Mass Spectrom. 2005, 40, 1197.

3. Brodie, R. R.; Chasseaud, L. F.; Rooney, L.; J. Chromatogr., B 1984, 310, 353 .

4. Brodie, R. R.; Chasseaud, L. F.; Darragh, A.; Lambe, R. F.; Rooney, L.; Taylor, T.; Biopharm. Drug Dispos. 1986, 7, 215.

5. Lucker, P. W.; Tinhof, W.; Wetzellsberger, N.; Weyers, W.; Brodbeck, R.; Arzneim. Forsch. 1983, 33, 453.

6. Imbs, J.; Leibenguth, A.; Koffel, J. C.; Jung, L.; Arzneim Forsch. 1982, $32,503$.

7. ICH - Harmonised Tripartity Guideline; Validation of Analytical Procedures: Text and Methodology Q2(R1). IFPMA:Geneva, 2005.

8. Ribeiro, F. A. L.; Ferreira, M. M. C.; Morano, S. C.; Silva, L. R.; Schneider, R. P.; Quim. Nova 2008, 31, 164.

9. The United States Pharmacopeia/The National Formulary; $30^{\text {th }}$ ed., Pharmacopoeial Convention: Rockville, 2006.

10. Chen, Y. Q.; Ni, Y. N.; Chinese Chem. Lett. 2009, 20, 615.

11. Silva, B. C.; Campos, L. M. M.; Nunan, E. A.; Soares, C. D. V.; Silva, G. R.; Ribeiro, J. A. A.; Pianetti, G. A.; Quim. Nova 2005, 28, 50.

12. Agência Nacional de Vigilância Sanitária (ANVISA); Resolução RE 899 de 29 de maio de 2003 - Guia para validação de métodos analíticos e bioanalíticos, Diário Oficial da União: Brasília, 2003.

13. Ribani M.; Bottoli, C. B. G.; Collins, C. H.; Jardim, I. C. S. F.; Melo, L. F. C.; Quim. Nova 2004, 27, 771.

14. Menegola, J.; Steppe, M.; Schapoval, E. E. S.; J. AOAC Int. 2008, 91,52.

15. Hurtado, F. K.; Nogueira, D. R.; Bortolini, F.; Da Silva, L. M.; Zimmermann, E.; Souza, M. J. E.; De Melo, J.; Rolim, C. M. B.; J. Liq. Chromatogr. R. T. 2007, 30, 1981.

16. De Melo, J.; Hurtado, F. K.; Prado, A. W.; Souza, M. J. E.; Rolim, C. M. B.; J. Liq. Chromatogr. R. T. 2008, 31, 269.

17. Fregonezi-Nery, M. M.; Baracat, M. M.; Casagrande, R.; Machado, H. T.; Miglioranza, B.; Gianotto, E. A. D. S.; Dalmas, J. C.; Quim. Nova 2008, 31, 1665 . 